\section{Nauplius}

The Journal OF The

Brazilian Crustacean Society

e-ISSN 2358-2936

www.scielo.br/nau www.crustacea.org.br

\title{
Two new burrowing mud shrimps of the genus Gilvossius from the Gulf of Mexico (Crustacea: Decapoda: Callianassidae)
}

\author{
Darryl L. Felder ${ }^{1}$ (1) orcid.org/0000-0001-7679-7712
}

Rafael Robles ${ }^{2}$ (1) orcid.org/0000-0003-0531-5557
1 Department of Biology, Laboratory for Crustacean Research, University of Louisiana at Lafayette. Lafayette, Louisiana USA 70504-3602
DLFE-mail: dlf4517@louisiana.edu
2 Facultad de Ciencias Químico Biológicas, Universidad Autónoma de Campeche, Campus V. Predio s/n por Avenida Ing. Humberto Lanz Cárdenas y Fracc. Ecológico Ambiental Siglo XXIII, Colonia Ex Hacienda Kalá, San Francisco de Campeche, Campeche, México 24085
RR E-mail: roblesrafaelr@gmail.com

ZOOBANK: http://zoobank.org/urn:1sid:zoobank.org:pub:55D1E70A-AAF5-4D17B72D-EC7997B42950

\section{ABstract}

Previous reports of Gilvossius setimanus (De Kay, 1844) from the Gulf of Mexico have been based on a population of small specimens from deep offshore continental shelf waters off Texas and larger specimens from shorelines and shallow embayments of western Florida. The offshore population, herein designated Gilvossius fredericqae n. sp., reaches sexual maturity at much smaller size than does Gilvossius setimanus s.s. from the U.S. Atlantic seaboard, a species from which it differs in a number of morphological characters. While maturing at a similar size to G. setimanus s.s., a western Florida population, herein designated Gilvossius howellorum n. sp., differs from it in the $16 \mathrm{~S} \mathrm{mt}$ gene sequence, and from both it and the offshore species in morphology. An updated synonymy and rediagnosis of G. setimanus s.s. herein accompany descriptions of the two new species.

\section{KEYWORDS}

Ghost shrimp, infauna, western Atlantic, Gulf of Mexico, systematics

CORRESPONDING AUTHOR Rafael Robles roblesrafaelr@gmail.com

SUBMITTED 13 December 2019 ACCEPTED 03 March 2020 PUBLISHED 15 June 2020

DOI 10.1590/2358-2936e2020018

\section{(cc) BY}

All content of the journal, except where identified, is licensed under a Creative Commons attribution-type BY.

Nauplius, 28: e2020018 
by Rabalais et al. (1981) from deep offshore waters of the northwestern Gulf were found to be fully mature (carrying embryos) at much smaller sizes than the relatively nearshore populations from near the type locality on the U.S. Atlantic seaboard. Figures accompanying the report by Rabalais et al. (1981: fig. 2a-h) combined specimens from both Texas and the Atlantic seaboard populations in attempting to represent morphology of what was therein regarded as a single species, but the accompanying analyses did not compare morphology of the populations. While not commented upon in that report, their illustration of a Gulf of Mexico specimen (Rabalais et al. 1981: fig. $2 \mathrm{~g}$ ) does clearly show a median spine on the telson, a sometimes subtle character shared with the Atlantic seaboard population (Williams, 1984: fig. 125d), even though these two populations can be seen to differ markedly in other morphological features, size, and ecology.

Very similar to the Atlantic seaboard population in general habitus, size, and ecology, another population of large specimens from shorelines and embayments of western to southeastern Florida was found to consistently lack this median spine, prompting further comparisons of its morphology to the more northern Atlantic seaboard population. As genesequence quality specimens were in this case available for both populations, $16 \mathrm{~S}$ mt DNA comparison was also undertaken.

We here describe two new species of Gilvossius Manning and Felder, 1992, differentiating both from G. setimanus. In support of this separation, we also provide an updated synonymy, rediagnosis, and reanalysis of distributional records for G. setimanus.

\section{Material and Methods}

Specimens from the Texas outer continental shelf were collected as described by Rabalais et al. (1981) and made available to us by N. Rabalais (LUMCON Marine Laboratory, Cocodrie, Louisiana), if not previously archived under existing collection catalog numbers. Specimens from western and southwestern Florida coasts were obtained by sieving of sediments hand-extracted with yabby pumps. Bottom depths at collection sites are shown in meters $(\mathrm{m})$. Fresh specimens were flash frozen briefly before being photographed, and then fixed directly in $75 \%$ ethyl alcohol. Digital color photographs of fresh and preserved specimens were made with subjects immobilized below the water surface of a shallow tray lined with black felt for framing of the exposure. Procedures for tissue extraction and sequence analysis were as previously described by Robles et al. (2009). Line illustrations were prepared with a Wild M5 dissecting microscope equipped with a camera lucida, after staining with Chlorazole BlackE when necessary. Postorbital carapace length (pocl) was measured to the nearest $0.1 \mathrm{~mm}$ from the posterior orbital margin at the base of the rostrum to the posterior margin of the carapace (= postrostral carapace length); embryo diameter size range was determined as the greatest dimension (to nearest $0.05 \mathrm{~mm}$ ) of five embryos on ovigerous females; for photographed major chelipeds, measurements were indicated as total propodus length (prpdl), including the fixed finger, to the nearest 0.1 $\mathrm{mm}$. Measurements were determined with a calibrated ocular micrometer or dial calipers. Cited specimens are archived in the Smithsonian Institution National Museum of Natural History, Washington, D.C., USA (USNM), Yale Peabody Museum of Natural History, New Haven, Connecticut, USA (YPM), or Museums Victoria, Melbourne, Australia (NMV). As holdings of the University of Louisiana's Lafayette Zoological collection (ULLZ), Lafayette, Louisiana, USA, are currently being transferred to the USNM, where the two catalog systems will be cross-referenced, a number of specimens are shown with both numbers indicated. Cited GenBank sequences were as accessioned by Felder and Robles (2009) and Robles et al. (2020), with addition of a single $16 \mathrm{~S}$ mtDNA sequence for Gilvossius setimanus s.s. obtained by the same protocol.

\section{Systematics}

Infraorder Axiidea de Saint Laurent, 1979

Family Callianassidae Dana, 1852

Gilvossius Manning and Felder, 1992 
Type species. Gonodactylus setimanus De Kay, 1844 (for generic diagnosis and recent synonymy see Poore et al., 2019).

\section{Gilvossius setimanus (De Kay, 1844)}

(Figs. 1, 6 A-C)

Gonodactylus setimanus De Kay, 1844: 34, pl. 8, fig. 23. Callianassa stimpsoni Smith, in Verrill, Smith and Harger, 1873: 549, pl. 2, fig. 8.

Callianassa stimpsoni.- Kingsley, 1878: 327 (appendix page 12); Kingsley, 1879: 410; Kingsley, 1899: 823 (text fig. 6), 824 (key); Borradaile, 1903: 548; Rathbun, 1905: 17; Fowler, 1912: 570-571; Sumner et al., 1913: 141; Hay and Shore, 1918, 406, pl. 28, fig. 5; Fish, 1925: 159.

Callianassa atlantica Rathbun, 1926: 107.

Callianassa atlantica.- Rathbun, 1935: 104; Schmitt, 1935: 4; Williams, 1965: 100 (key), 101, 102 (part, not Franklin County, Florida), fig. 79; Biffar, 1970: 48, tab. 2; Biffar, 1971a: 639-641, 652-654 (key), 671, 694; Biffar, 1971b: 229; Williams, 1974: 16 (key), 41 (part, not Franklin County, Florida), fig. 43A, B; Rabalais et al., 1981: 101 (part, not Gulf of Mexico), fig. 2b, c, e, f, h; Williams, 1984: xiii, 180, 181 (part, not Franklin County, Florida), fig. 125a-d; Abele and Kim, 1986: 26 (part, not Franklin County, Florida), 294 (key), 297, 300 (legends a, b, c), 301 (figs. a, b, c); Manning and Felder, 1991: 765.

Callianassa (Callichirus) atlantica.- de Man, 1928a: 37, pl. 9, fig. 17-17d; de Man, 1928b: 28, 94, 112; Williams, 1965: 102, fig. 79.

Callichirus atlantica.- Gurney, 1944: 89.

Callianassa setimanus.- Manning, 1987: 386-388 (part, not Gulf of Mexico).

Gilvossius setimanus.- Manning and Felder, 1992: 558-560 (part, not Miami and Gulf of Mexico),

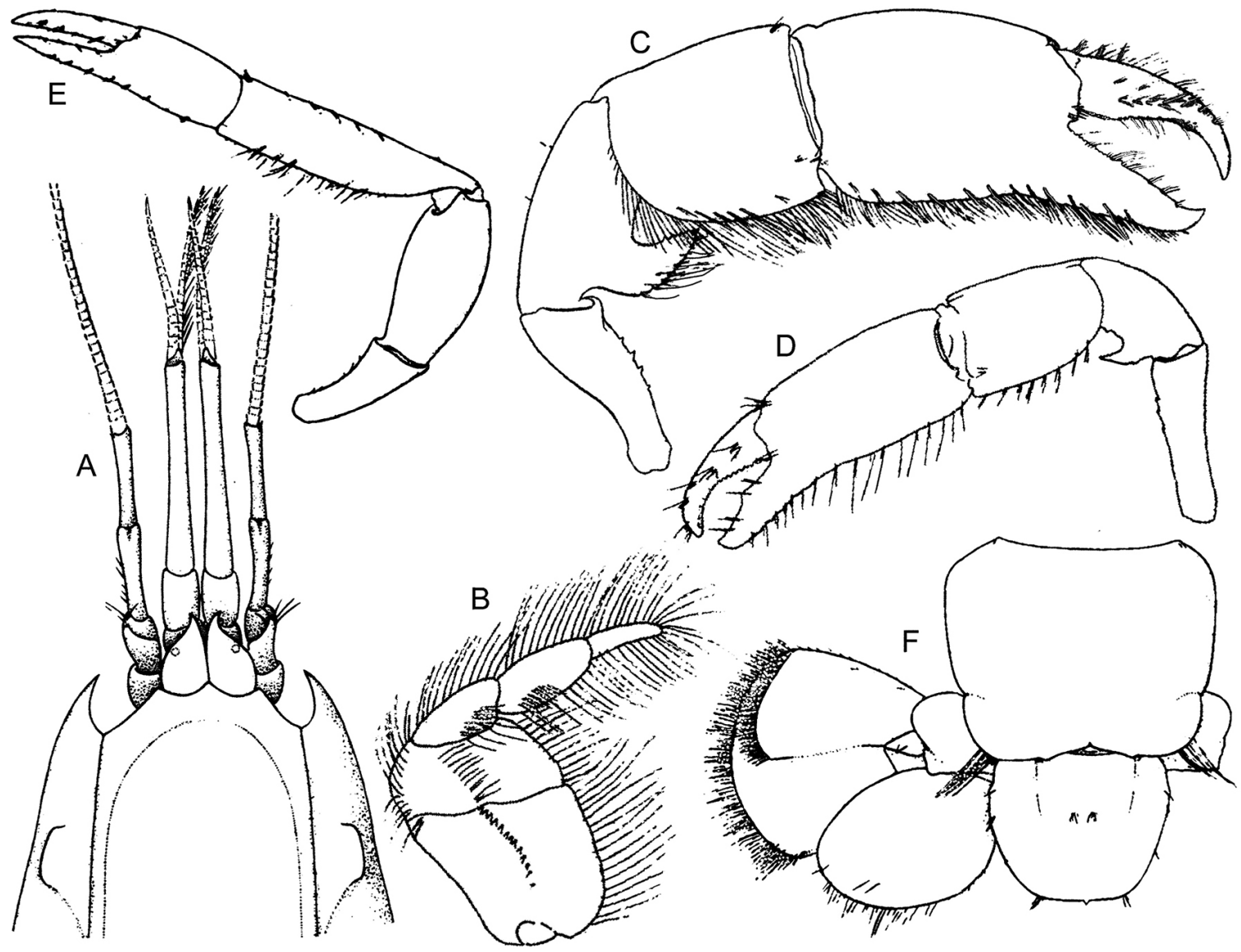

Figure 1. Gilvossius setimanus s.s., adapted from Williams (1984: fig. 125a-d), male, USNM 14096 (A, C, E, F) and from Rabalais et al. (1981: fig. 2b, c) female, USNM 51007 (B, D). A, anterior carapace, eyes, antennules, and antennae, dorsal surfaces; B, third maxilliped, internal surface; C, D, major cheliped, external surface; E, minor cheliped, external surface; F, sixth pleonal somite, telson, and left uropods, dorsal surfaces. Not shown to scale. 
fig. 1a-g; Tudge et al., 2000: 133-134, 136, 143, 147, figs 3, 4; Heard et al., 2007: 16 (key), 21-22 (part, not Gulf of Mexico), fig. 24; Felder et al., 2009: 1062, 1093 (part, not Gulf of Mexico and Colombia); Sakai, 2005: 47-48 (part, not Gulf of Mexico and Colombia); Sakai, 2011:372-373, 374 (key), 378-379 (part, not Gulf of Mexico and Colombia); Dworschak et al., 2012: 177, 192.

Callianassa setimana.- Sakai, 1999: 29 (part, not Gulf of Mexico and Colombia).

Materials examined. Atlantic coast U.S.A. (type not extant). Florida: 1 immature female, pocl 7.2 mm (USNM 1549424 = ULLZ 16231), Fort Pierce Inlet, Dynamite Point, intertidal sand flat, $27^{\circ} 28.40^{\prime} \mathrm{N}$ $80^{\circ} 17.79$ 'W, 27 July 2005. North Carolina: 1 female, pocl $7.8 \mathrm{~mm}$ (USNM 51007), just outside Beaufort Harbor, R/V Fish Hawk, dredge, 23 m depth, 34³7'N 7695'W, 7 September 1913. Rhode Island: 1 female (photograph voucher), pocl $12.5 \mathrm{~mm}$ (USNM 20869), Newport shoreline, 1880. Connecticut: 1 mutilated female (DNA voucher), carapace missing (YPM IZ 067307), Long Island Sound, Thimble Islands, muddy sand, $0-0.5 \mathrm{~m}$ depth, $41^{\circ} 14.61^{\prime} \mathrm{N} 72^{\circ} 45.53^{\prime} \mathrm{W}$, 14 August 2013. Massachusetts: 1 female, pocl 9.2 mm (USNM 12902), Buzzards Bay, Naushon Island, 19 September 1887; 1 male, pocl 28.5 mm (USNM 14096), Martha's Vineyard, R/V “Fish Hawk”, dredge, 7-18 $\mathrm{m}$ depth, 6 September 1883; 1 male (photograph voucher), pocl $13.9 \mathrm{~mm}, 1$ female (photograph voucher), pocl $15.5 \mathrm{~mm}$ (USNM 9238), Woods Hole, 19 November 1884.

Morphological diagnosis. Antennular peduncle third (distal) article 4-5 times length of second (penultimate) article (sometimes shorter in juveniles). Adult eyestalks terminated distally in distinctly divergent elongate spines. Second maxilliped exopod equal to length of endopod merus, endopod with propodus length more than three times propodus width. Third maxilliped with operculiform ischiummerus subrectangular in outline, width of ischium less than length. Adult male major chela fixed finger opposable margin with primary tooth positioned at or proximal to midlength, distal slope of tooth commonly forming abrupt marginal offset or abutting small notch, opposable margin serrate (coarsely granulate or denticulate) proximal to primary tooth (primary tooth sometimes no larger than others near midlength of finger, especially in females). Third pereopod propodus with distoventral margin cuspate, marginal setation separated into distinct clusters. Telson rounded over posterior half, posterior margin with small median spine (sometimes as minute vestige).

Diagnostic gene sequence. GenBank accession number for YPM IZ 067307: (16S) MN726521.

Habitat. The confirmed depth range remains as stated by Williams (1984), who reported the species from intertidal shores to subtidal waters of about 38 $\mathrm{m}$ depth. The much greater offshore depths reported by Manning (1987: 386) and Felder et al. (2009: 1062) were based on northwestern Gulf of Mexico populations (sensu Rabalais et al., 1981) that are no longer assignable to this species. Habitats include muddy sands of beaches, intertidal to shallow subtidal shoals and sand bars, embayments, and nearshore bottoms of open waters.

Distribution. Bass River Nova Scotia, south along U.S. Atlantic seaboard to vicinity of Fort Pierce Inlet, Florida.

Remarks. Manning (1987) reviewed history pertaining to the mutilated type of this species, which was originally reported as a new species of stomatopod taken from the stomach of a commercial cod in a New York fish market. While the fragmentary type specimen is no longer extant, other intact materials taken from near the type locality are now accepted to represent the species. Williams (1984: 181) reviewed a number of additional references that almost certainly apply to reproductive periodicity and larval life history of this species, though some, like that of Frankenberg and Leiper (1977), are now known to instead represent Biffarius biformis (Biffar, 1971b) (see Rabalais et al., 1981: 112). The distributional range reported by Williams (1984: 181), and repeated by Abele and Kim (1986: 26) extended to the coast of Franklin County in the panhandle of Florida, bordering the northeastern Gulf of Mexico. However, no specimens have been located in the USNM or elsewhere to suggest that this record might indeed represent G. setimanus s.s., and 
that report is deemed to more likely represent one of the new species in the accounts that follow.

The history of generic reassignments of this species and its congeners by Sakai $(1999 ; 2005 ; 2011)$ was reviewed by Poore et al. (2019), who rediagnosed and clarified membership of the genus, drawing upon morphological and molecular phylogenetic analyses by Robles et al. (2020). The report of Callianassa setimana from Caribbean waters of Colombia by Sakai (1999: 29) is not for the present included in the distributional range of G. setimanus s.s. Reported without supporting illustrations or comparative analyses, that identification was apparently based solely on juvenile specimens taken from a tropical locality that is widely disjunct from confirmed populations of this species.

The Miocene and Pleistocene fossils reported as Callianassa atlantica Rathbun, 1926 s.l. by Rathbun (1935) are not here included in the synonymy for $G$. setimanus, though at least some could represent historical populations of the species. While those specimens originated from sites in Maryland, Virginia, and North Carolina that fall within the modern coastal range of the species, subtle morphological distinctions now used to separate G. setimanus s.s. from its congeners cannot be readily applied to fragmentary fossil materials.

\section{Gilvossius howellorum n. sp.}

(Figs. 2, 3, 6D-F)

Zoobank: urn:1sid:zoobank.org:act:619EC744BAD2-4F0E-B09A-326CA8444C97

Callianassa atlantica.- Williams, 1965: 103 (part? Franklin County, Florida?); Williams, 1974: 41 (part? Franklin County, Florida?); Williams, 1984: 181 (part? Franklin County, Florida?).

Gilvossius setimanus.- Manning and Felder, 1992: 558

(part, Rickenbacker Causeway, Miami, Florida only); Felder and Robles, 2009: 335, 336, tab. 1, fig. 1; Felder et al., 2009: 1062, 1093 (part, northeastern Gulf of Mexico and Tampa Bay, Florida only); Poore et al., 2019: 94 (part, molecular evidence attributed to Robles et al., 2020).

Type material. Western to southeastern coasts of Florida (northeastern Gulf of Mexico to Biscayne
Bay). Holotype: male (DNA and photograph voucher), pocl $12.4 \mathrm{~mm}$, (USNM $1546234=$ ULLZ 12183), < $1 \mathrm{~m}$ depth, subtidal sand flat, Pinellas Point, lower Tampa Bay, St. Petersburg, 3 September 2010. - Paratypes: 1 ovigerous female (DNA voucher), pocl $11.5 \mathrm{~mm}$, embryo diameter $1.02-1.17 \mathrm{~mm}$ (USNM 1540396 = ULLZ 4500 TB-A), $<1 \mathrm{~m}$ depth, subtidal sand flat, Pinellas Point, lower Tampa Bay, St. Petersburg, 8 May 2001; 1 male (DNA voucher), pocl $8.6 \mathrm{~mm}$ (USNM $1607368=$ ULLZ $4500 \mathrm{~TB}-\mathrm{B})$, data same as preceding; 1 ovigerous female (DNA voucher), pocl $12.5 \mathrm{~mm}$ (USNM $1607369=$ ULLZ 4500 TB-C), data same as preceding; 1 male, pocl $7.6 \mathrm{~mm}, 1$ female $11.0 \mathrm{~mm}$, embryo diameter $1.00-$ $1.10 \mathrm{~mm}$ (USNM $1607370=$ ULLZ 4500 TB-D), data same as preceding; 1 male, pocl $10.5 \mathrm{~mm}, 1$ ovigerous female, pocl $12.8 \mathrm{~mm}$ (NMV J-58373), data same as preceding; 1 ovigerous female (DNA voucher, atypical chelipeds), pocl $7.6 \mathrm{~mm}$ (USNM 1543411 = ULLZ 7919), < $1 \mathrm{~m}$, sand bar, mouth of Tampa Bay, St. Petersburg, 17 August 2005; 1 male (cheliped photograph voucher), pocl $12.2 \mathrm{~mm}$, (USNM uncataloged), Anna Maria Island Causeway, Manatee County, Florida, 15 April 1988; 1 female, pocl $6.0 \mathrm{~mm}$ (USNM 221848), shallow subtidal flat, west side of Key Biscayne, 28 May 1988.

Morphological diagnosis. Antennular peduncle third (distal) article 3-4 times length of second (penultimate) article. Adult eyestalks terminated in short, subtriangular, weakly divergent tips. Second maxilliped exopod equal to or exceeding length of endopod merus, endopod with propodus length more than three times propodus width. Third maxilliped operculiform, ischium-merus subrectangular in outline, width of ischium less than greatest length. Adult male major chela fixed finger with primary tooth positioned near or distal to midlength (rare cases slightly proximal), finger margin distal and proximal to tooth broadly depressed or concave, distal slope of tooth usually lacking abrupt marginal offset, tooth not positioned against small marginal notch. Third pereopod propodus inferodistal margin cuspate, marginal setation separated into dense tufts on marginal elevations. Telson rounded over posterior half, posterior margin lacking median spine. 


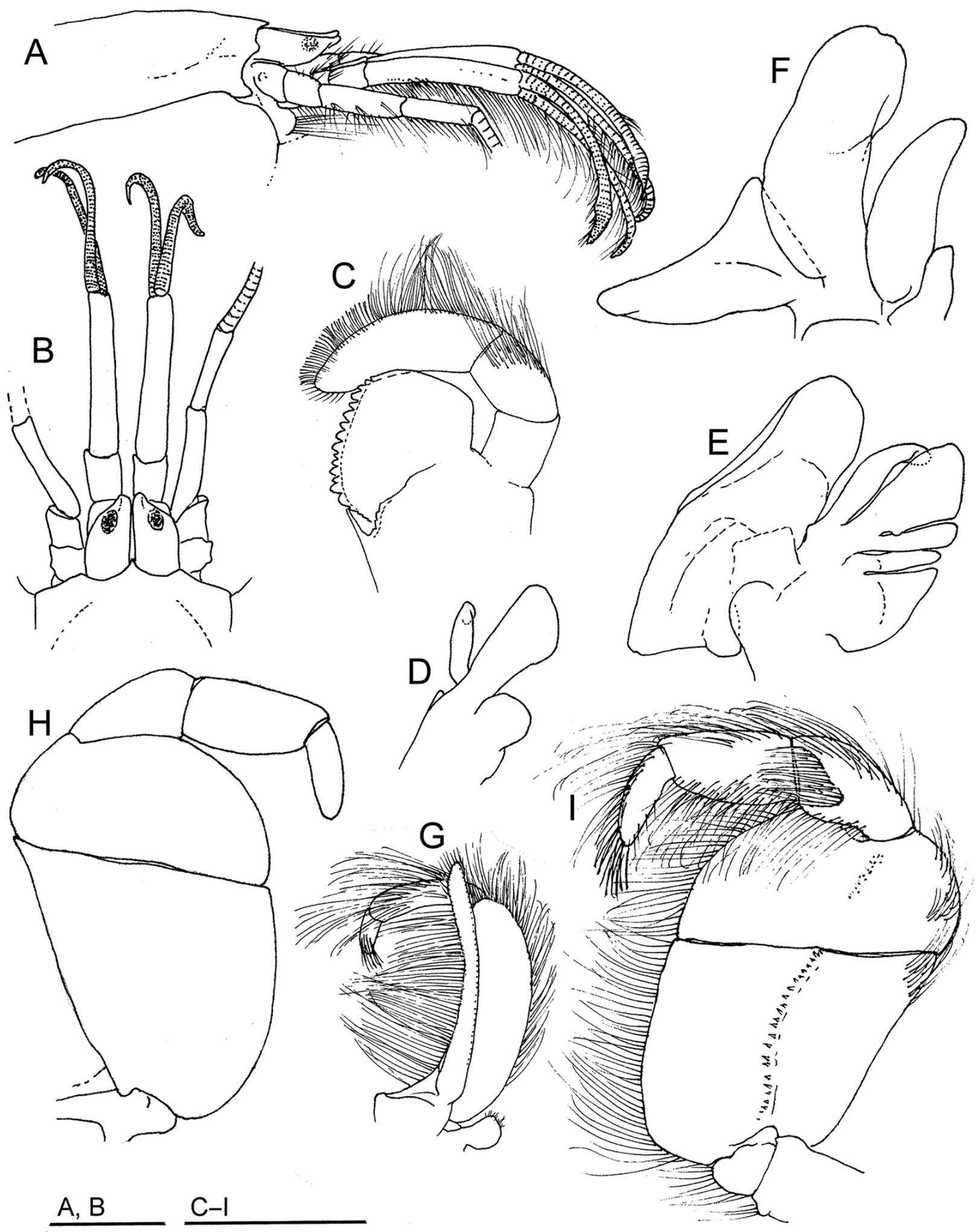

Figure 2. Gilvossius howellorum n. sp., male holotype, pocl $12.4 \mathrm{~mm}$, lower Tampa Bay, St. Petersburg, Florida, shallow subtidal flat (USNM 1546234 = ULLZ 12183): A, B, anterior carapace, eyes, and peduncles, lateral and dorsal; C, right mandible, internal; D, right first maxilla, external; E, right second maxilla, external; F, right first maxilliped, external; G, right second maxilliped, internal; H, right third maxilliped without setae, external; I, right third maxilliped, internal. Scale bars = $3.0 \mathrm{~mm}(\mathbf{A}, \mathbf{B}, \mathbf{D}-\mathbf{I}), 1.5 \mathrm{~mm}(\mathbf{C})$. 


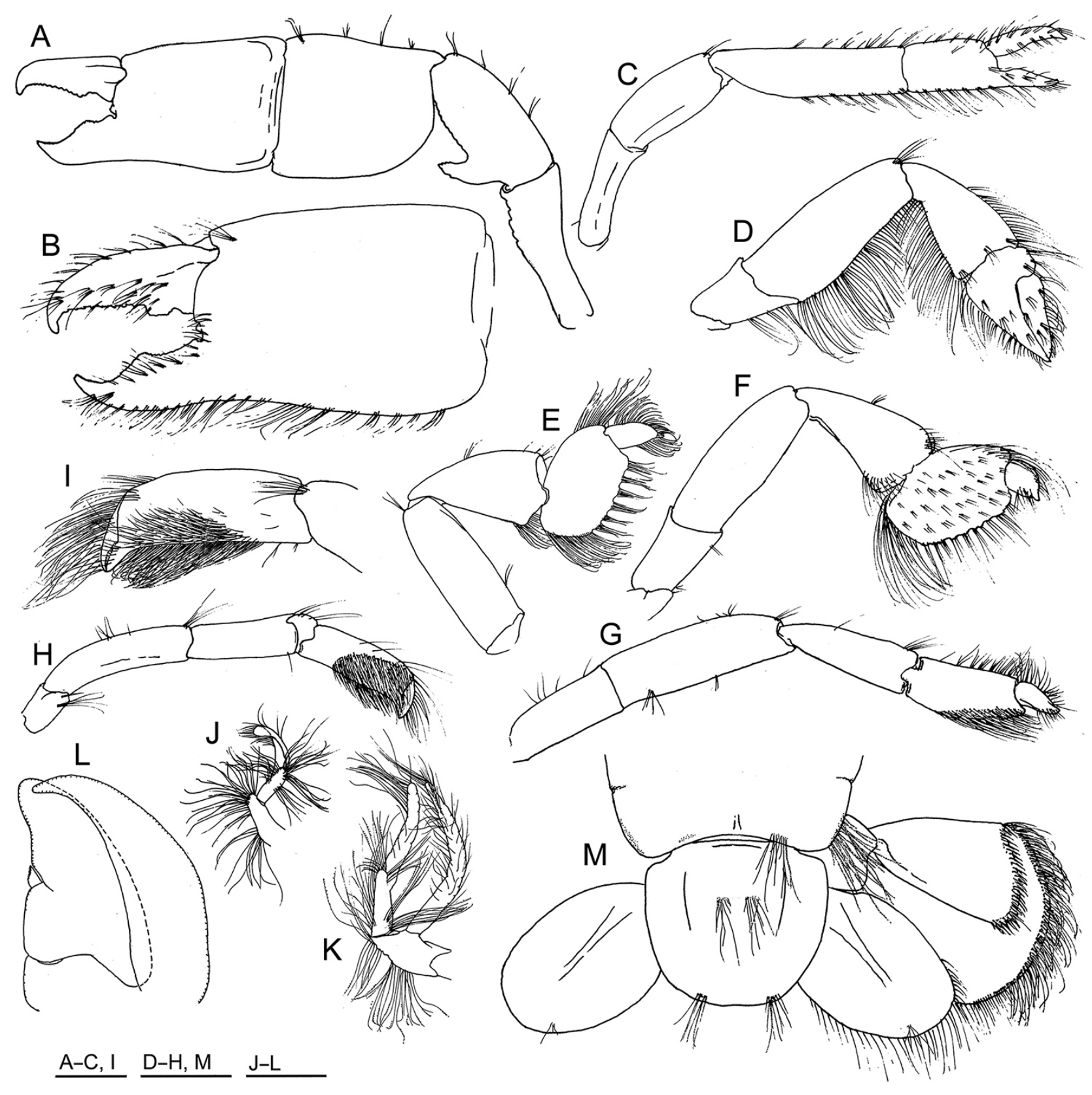

Figure 3. Gilvossius howellorum n. sp. A, E, J-L, ovigerous female paratype, pocl 11.5 mm, lower Tampa Bay, St. Petersburg, Florida, shallow subtidal flat (USNM 1540396 = ULLZ 4500TB-A); B-D, F-I, M, male holotype, pocl 12.4 mm, lower Tampa Bay, St. Petersburg, Florida, shallow subtidal flat (USNM 1546234 = ULLZ 12183). A, female major cheliped, external; B, male major chela, external; C, minor cheliped; D, right second pereopod, external; E, left third pereopod, internal; F, right third pereopod, external; G, left fourth pereopod, internal; H, right fifth pereopod, external; I, right fifth pereopod terminus, internal; J, female right first pleopod, external; K, female right second pleopod, external; L, right third pleopod, anterior; $\mathbf{M}$, telson and uropods, dorsal, right uropodal setation shown. Scale bars $=3.0 \mathrm{~mm}(\mathbf{A}-\mathbf{H}, \mathbf{J}-\mathbf{M}), 1.5 \mathrm{~mm}(\mathrm{I})$.

Diagnostic gene sequences. GenBank Accession numbers for paratypes USNM 1540396 (= ULLZ 4500 TB-A), USNM 1607368 (= ULLZ 4500 TBB), USNM 1607369 (= ULLZ 4500 TB-C), and (USNM 1543411 = ULLZ 7919): (16S) EU882934,
EU882935, EU882936, EU874924; (12S) EU875044, EU875045, EU875046, MN238478; (18S) MN237985, MN237986, MN237987, EU874974; (H3) MN238221, MN238222, MN238223, MN238294. 
Description. Carapace frontal margin with short, broad, triangular rostrum, rostrum flattened in lateral view, terminally subacute, not reaching to corneas of eyestalks, rostral base flanked laterally by low, bluntly subtriangular shoulders forming orbits (Figs. 2A, B; 6D-F); rostral tip not exceeding $1 / 3$ length of eyestalks in dorsal view; dorsal oval weakly defined, becoming obscure near post-rostral midline.

Eyestalks elongate, reaching to penultimate (second) article of antennular peduncle, straplike, subrectangular in dorsal view, carried slightly deflected, divergent subtriangular tips subacute, slightly upturned distally (Figs. 2A, B; 6D-F); medial borders of stalks closely opposed for most of length, meeting along nearly straight line, dorsal surfaces elevated near medial borders, sloping to more narrowly flattened distolateral margins; white corneal pigment well defined in life, corneal surface weakly faceted.

Antennular peduncle longer and distinctly heavier than antennal peduncle, length of distal antennular peduncle article 2 times length of distal antennal peduncle article (Fig. 2A, B); second (penultimate) article shorter than basal, third (distal) article about 4 times length of second; second and third articles with ventromesial and ventrolateral rows of long, distoventrally directed setae. Antennular flagellum dorsal and ventral rami slightly longer than third article of peduncle, ventral with longer setation than dorsal ramus; dorsal ramus heavier than ventral, especially in distal $1 / 3$ where broadest subterminal articles fringed with, dense ventral aesthetascs. Antennal peduncle reaching into distal $1 / 4$ of third antennular peduncle article; basal article dorsolateral carina arched to form lip above excretory pore; length of second article slightly exceeding width, distal articulation to third article with weak scaphocerite; fourth article exceeding combined lengths of first three, distinctly longer than fifth, fourth and fifth ventrally setose; fifth article slightly narrower than others. Antennal flagellum about 3 times longer than rami of antennular flagellum, antennal flagellum setation sparse, setae very thin, 1-4 articles in length.

Mandibular palp 3-segmented, elongate third article heavy, arched, dense elongate setae on second article and proximally on third, dense short stiff brush of setae on distal half of third (Fig. 2C); gnathal lobe of mandible distinctly subquadrate, distolateral shoulder forming rounded obtuse angle, incisor process with about 15 well-defined subtriangular corneous teeth on cutting margin, concave internal face with thickened lip giving rise to weakly dentate molar process positioned proximal and internal to incisor teeth. First maxilla endopodal palp narrow, tip of terminal article deflected (Fig. 2D); proximal endite forming rounded mesial lobe; distal endite elongate, terminally broadened with dense setation. Second maxilla margins setose, endopod narrow, strap-like, terminus wrapping behind adjacent endite (Fig. 2E); first and second endites each longitudinally subdivided, exopod forming large, broadly cupped scaphognathite, distal lobe rounded, proximal lobe subangular.

First maxilliped margins setose, endopod very small, concealed between base of distal endite and exopod (Fig. 2F); distal endite weakly arcuate, narrowing distally to rounded terminus, external surfaces densely setose medially and terminally; exopod elongate, subrectangular, weakly arcuate, incompletely divided by oblique suture, close-set comb of very long plumose setae on mesial margin, those near oblique suture longer than others; epipod shorter than exopod, broadly triangular, anterior and posterior lobes narrowing to rounded angles

Second maxilliped small, margins of both rami setose; endopod merus weakly arcuate, broadest proximally, length exceeding 3 times width, exceeding combined length of subcylindrical propodus and dactylus, length of narrowly elongate propodus about 4 times width, length equal to or exceeding $1 / 2$ length of merus (Fig. 2G); dactylus about twice as long as broad, rounded terminally; exopod narrow, strap-like, carried closely against internal surface of endopod, distinctly longer than endopodal merus, terminally rounded; small rounded epipod present, vestigial branchiae lacking.

Third maxilliped lacking exopod, ischium-merus operculate in form, palp digitiform (Fig. 2H, I); endopod fringed by long setae, especially on mesial margins of ischium and merus, along with most of palp articles; ischium subrectangular, greatest length exceeding width, internal surface with slightly arcuate longitudinal row of minute, terminally cornified, spiniform teeth forming low crista dentata; merus much broader than long, length about $1 / 2$ length of 
ischium; carpus as broad as propodus, both longer than broad, both with dense field of setae on internal surface, propodus subcylindrical, length near 2 times width; dactylus digitiform, length exceeding 2 times breadth, weakly arcuate, terminally bearing long, stiff bristles.

First pereopods strongly heterochelous in both sexes (Figs. 3A-C, 6D-F); major cheliped located on either right or left side, shape and ornamentation somewhat sexually dimorphic, typically heavier, stouter, more coarsely ornamented in mature male than in female; ischium slender, superior margin slightly arched or sinuous, inferior marginal carina weakly armed by row of small denticles distally; merus superior margin smooth, slightly depressed in proximal third, sloping smoothly to rounded longitudinal carina subdividing upper and lower halves of external surface, longitudinal carina weakly undercut by longitudinal furrow, terminated proximally where incised by arched furrow above proximal lobe on ventral keel; inferior (flexor) margin forming keel bearing line of subacute denticles, keel proximally bearing broad hooked lobe, terminated in single or multiple denticles, distal and proximal margins of lobe usually armed with additional denticles, most acute on distal margin, larger and usually more rounded on proximal; carpus broad, subquadrate, superior and inferior margins keeled, superior margin bearing few short setae, inferior margin bear few if any setae, terminating distally in acute to subacute angular corner; propodus broad, heavy, median length of postdactylar palm exceeding length of carpus, about two times length of fixed finger, superior and inferior margins keeled proximally, inferior margin with rows of punctae to internal and external sides bearing tufts of long setae, sparsely setose along superior margin, opposable edge of fixed finger with primary tooth positioned near or distal to midlength (rare cases slightly proximal), finger margin distal and proximal to tooth broadly depressed, concave, distal slope of tooth usually lacking abrupt marginal offset, tooth not positioned against small marginal notch; dactylus superior margin with array of large punctae bearing tufts of long setae to either side of dorsal crest, extending to near tip, opposable edge with subquadrate to subtriangular tooth proximally, remainder lined by uniform low denticles diminishing in size distally, weak submarginal longitudinal depression to internal side of edge, external side marked by row of large punctae bearing tufts of long setae, tip strongly hooked.

Minor cheliped ischium narrowly elongate (Figs. $3 C$; 6D, E), inferior margin at most weakly serrated by low denticles; merus subrectangular, unarmed; carpus narrow at proximal articulation, elongate with parallel superior and inferior margins in distal half, about twice length of palm (Figs. 3C; 6D, E); inferior margins of carpus and propodus bearing slightly longer, denser setae than superior; fixed finger length less than length of palm, fixed finger opposable margin usually with weakly elevated tooth in proximal half, dactylus weakly sinuous, fingers closely opposed, minimal gape, tips acute.

Second pereopod chelate, finger lengths exceeding height of palm; flexor margin of merus and carpus lined by long regularly spaced setae, inferior margin of propodus and superior margin of dactylus similarly setose, setae becoming shorter, stiffer, becoming more hooked distally (Fig. 3D); external surfaces of distal propodus and dactylus with few flattened tufts of setae.

Third pereopod merus length less than 3 times width; propodus with inferodistal margin cuspate, marginal elevations bearing dense tufts of elongate setae (Fig. 3E, F), external surface covered by tufts of short setae; dactylus tear-shaped, concealed by long dense setae on external surface, article terminating in elongate, narrow, laterally directed corneous spine. Diameter of female gonopore less than $1 / 2$ length of coxa.

Fourth pereopod very weakly subchelate, inferodistal process of propodus (= fixed finger) developed as a low densely setose rounded lobe extending distally about $1 / 4$ length of dactylus (Fig. 3G); dactylus elongate, weakly sinuous, tapering distally, tip twisted to terminate in ventrolaterally directed triangular tooth.

Fifth pereopod minutely but distinctly chelate terminally amid dense setation, opposable surfaces of fingers slightly spooned, terminally rounded (Fig. 3H, I); propodus with dense field of long, closeset setae on internal surface.

Branchiae limited to pair of arthrobranchs on third maxilliped and each of first through fourth pereopods. 
Pleonal tergites mostly smooth, glossy dorsally (Fig. 6D, E). First pleonal tergite well sclerotized dorsally, lacking transverse furrow in anterior half, sclerite extended posteroventrally as narrowing lobe, subdivided by conspicuous poorly sclerified furrow. Second tergite about $1 \frac{1}{2}$ times length of first, tergite ventral margin weakly bowed, rounded posterolateral lobe with scant setation limited to linear tuft. Third to fifth tergites each with very broad field of very fine soft setae overlying posterolateral lobe, that of third more posteriorly restricted than successively those on fourth and fifth, the fifth originating near midlength. Sixth tergite with distinct posterolateral groove and short suture defining posterolateral lobe, suture not extending across tergite, lobe with submarginal tuft of stiff setae posterolaterally, posterior margin of tergite with similar tuft to mesial side of lobe (Fig. 3M). Ventral surfaces of pleonal somites mostly membraneous, lacking extensive armor of sclerotized plates dense tubercles embedded in integument.

Male without first and second pleopods; female first pleopod uniramous, composed of 2 articles, bearing tufts of long setae along length; female second pleopod biramous (Fig. 3J, K), exopod bearing scattered tufts of elongate setae, narrow, bowed, reaching about to end of endopod when flexed against it, endopod with tufts of elongate setae, including at tip of appendix interna. Third to fifth pleopods forming large, posteriorly cupped fans, endopod of each subtriangular with short heavy appendix interna embedded in mesial margin, opposed surfaces on appendix internae of two sides each with small field of microscopic hook setae (Fig. 3L).

Telson wider than long, posterolateral to posterior margin distinctly rounded (Fig. $3 \mathrm{M}$ ), posterior margin without median spine in shallow depression; dorsal surface with weak median elevation in anterior $2 / 5$ bearing bilaterally separated small fields or tufts of setae.

Uropodal endopod broadly ovate, about $1 \frac{1}{2} 2$ times longer than broad, posterior margin with fringe of long setae, lacking marginal development of stiff spines and bristles, dorsal surface lacking stiff spines or bristles, at most with tuft or two of setae posteriorly (Fig. 3M); exopod anterodorsal plate strong, well developed, distally not reaching to endopod margin, setae along posterodistal edge of plate including slightly stronger spiniform bristles posteriorly, grading laterally to thinner, dense, elongate setae of exopod distal margin, continuous dense fringe of fine long setae on exopod distal and posterior margin, posterior margin lacking row of conspicuous stiff bristles.

Etymology. The name of this species honors Joan and George Howell, in recognition of funding provided to support environmental research and education at many levels, including contributions to our studies in marine biodiversity.

Size. Largest male pocl $12.4 \mathrm{~mm}$, largest female pocl $12.8 \mathrm{~mm}$. Smallest ovigerous female pocl 7.6 $\mathrm{mm}$. Range of embryo diameters, measured as greatest dimension, $1.00-1.17 \mathrm{~mm}$.

Habitat. Known only from deep burrows in intertidal to shallow ( $<1 \mathrm{~m}$ depth) muddy sand flats along shorelines of high salinity inlets and embayments, all known specimens having been extracted with hand-operated yabby pumps.

Distribution. Tampa Bay to Anna Maria Island on the western coast of Florida; Biscayne Bay on southeastern coast of Florida.

Remarks. Molecular genetic comparisons of Gilvossius howellorum n. sp. to G. setimanus s.s. were for the present limited to $16 \mathrm{~S} \mathrm{mt}$ sequence data. However, the morphologically based separation of these two somewhat similar species is clearly supported at a level of sequence divergence found between other pairings of congeneric callianassid species. For example, species of Lepidophthalmus Holmes, 1904 show sequence divergence from 5.3 to 10.3\% (Robles and Felder, 2015). Our measured 16S sequence divergence between analyzed specimens of Gilvossius howellorum n. sp. and those of G. setimanus s.s. ranged from 18.1 to $19.1 \%$.

Gilvossius howellorum n. sp. and G. setimanus attain maturity at a similar size, and both species appear to be coastally restricted. This, and the posteriorly rounded telson in both, readily separates them from a second new offshore species from the northwestern Gulf of Mexico, to be treated below. While very similar in general habitat and habitus, these species can be 
separated morphologically by close inspection of the posterior margin of the telson, which bears a very small median spine in G. setimanus and lacks it in G. howellorum n. sp. Very careful microscopic study is sometimes required, as this spine can be minute, concealed among setae, translucent in long-preserved specimens, folded beneath the telson margin, or damaged in varied ways. It is not usually set into a conspicuous median marginal depression. Separation of the two species can also often be based on sculpture and dentition of the adult male major chela fixed finger. In G. howellorum n. sp., the opposable margin is typically armed with a broad-based primary tooth with its apex centered near the finger midlength, distal to it, or slightly proximal to it (Fig. 6D-F); when normally developed, the marginal slopes of this tooth distal and proximal to the apex are broadly depressed or concave, with the distal slope not forming an abrupt marginal offset or positioned against a marginal notch. In G. setimanus, the opposable margin of the adult male major chela fixed finger typically has the primary tooth, when present (often absent in females), positioned at midlength or proximal to it, with the distal slope of this tooth commonly forming an abrupt marginal offset or positioned to butt against a small notch (Fig. 6A-C); when the primary tooth is present, the margin proximal to the tooth apex is typically more distinctly serrate (coarsely granulate or denticulate) than is the margin distal to it. In addition, the terminal spines of the ocular peduncles in mature specimens of G. setimanus are often, though not always, more elongate and strongly divergent than are the typically less produced tips of the peduncles in G. howellorum n. sp.

The specimen referred to by Manning and Felder (1992: 558) from the Rickenbacker Causeway, Miami, Florida, now cataloged (USNM 221848), is now regarded to represent $G$. howellorum n. sp. As also noted in the preceding treatment of G. setimanus, the distribution of that species reported by Williams (1984) and Abele and Kim (1986) included Franklin County, Florida, in the northeastern Gulf of Mexico. While no archived materials from that site have been located, prompting their listing under questionable status in the synonymy above, coastal habitats there would now be regarded as likely inhabited by $G$. howellorum n. sp. than by G. setimanus s.s.

\section{Gilvossius fredericqae n. sp.}

(Figs. 4, 5, 6G)

Zoobank: urn:1sid:zoobank.org:act:61F5311EC506-4E23-B592-B03F3F32C673

Callianassa atlantica.- Rabalais et al., 1981: 96, 99, 101-103 (part, Gulf of Mexico only), 107, 110-112 (part, Gulf of Mexico only), tab. 1, fig. 2a, d, g (only), figs. 5A, B, 6A-E.

Callianassa setimanus.- Manning, 1987: 386-388 (part, Gulf of Mexico only).

Gilvossius setimanus.- Heard et al., 2007: 21-22 (part, Gulf of Mexico only); Felder et al., 2009: 1062, 1093 (part, northwestern Gulf of Mexico only); Sakai, 2005: 47-48 (part, Gulf of Mexico only); Sakai, 2011: 372-373, 374 (key), 378-379 (part, Gulf of Mexico only).

Callianassa setimana.- Sakai, 1999: 29 (part, Gulf of Mexico only).

Type material. Off Texas coast, U.S.A. (northwestern Gulf of Mexico). Holotype: ovigerous female, pocl $4.0 \mathrm{~mm}$, embryos $0.65-0.75 \mathrm{~mm}$ (USNM 1607374 = ULLZ 17894), BLM/STOCS station 6/ II-6, depth 98 m, $27^{\circ} 24^{\prime} \mathrm{N} 96^{\circ} 29^{\prime} \mathrm{W}, 19$ November 1976. - Paratypes: 1 male, pocl $2.7 \mathrm{~mm}$ (USNM 1607375 = ULLZ 17495), BLM/STOCS station 3/ III-1, depth 106 m, 265' N 96³3' W, 19 February 1976; 1 ovigerous female, pocl $3.6 \mathrm{~mm}$ (USNM $1607376=$ ULLZ 17903), BLM/STOCS station 3/ II-5, depth $131 \mathrm{~m}, 27^{\circ} 18^{\prime} \mathrm{N} 96^{\circ} 23^{\prime} \mathrm{W}, 9$ December 1976; 2 females (larger one ovigerous), pocl 3.6, $2.4 \mathrm{~mm}$ (USNM 172306), BLM/STOCS station 3/II, depth $131 \mathrm{~m}, 27^{\circ} 18^{\prime} \mathrm{N} 96^{\circ} 23^{\prime} \mathrm{W}, 16$ May 1975; 1 juvenile male, pocl $2.3 \mathrm{~mm}$ (USNM $1607377=$ ULLZ 17904), BLM/STOCS station 6/III-5, depth 125 m, 265' $\mathrm{N} 96^{\circ} 30^{\prime} \mathrm{W}$, 27 June 1976; 1 mutilated juvenile male, pocl $2.4 \mathrm{~mm}$, (USNM $1607378=$ ULLZ 17905), BLM/STOCS station 6/I-2, depth 100 m, 27³9'N 96²' 'W, 1 June 1977; 1 juvenile male, pocl $2.2 \mathrm{~mm}$ (USNM 1607379= ULLZ 17906), BLM/STOCS station 6/III-3, depth $125 \mathrm{~m}, 26^{\circ} 58^{\prime} \mathrm{N}$ $96^{\circ} 30^{\prime} \mathrm{W}, 26$ May 1977; 1 juvenile female, 1 unsexed immature, pocl 2.2, $1.1 \mathrm{~mm}$ (USNM $1607380=$ ULLZ 17496), BLM/STOCS station 3/II-3, depth $131 \mathrm{~m}, 27^{\circ} 18^{\prime} \mathrm{N} 96^{\circ} 23^{\prime} \mathrm{W}, 27$ March 1976; 1 juvenile 


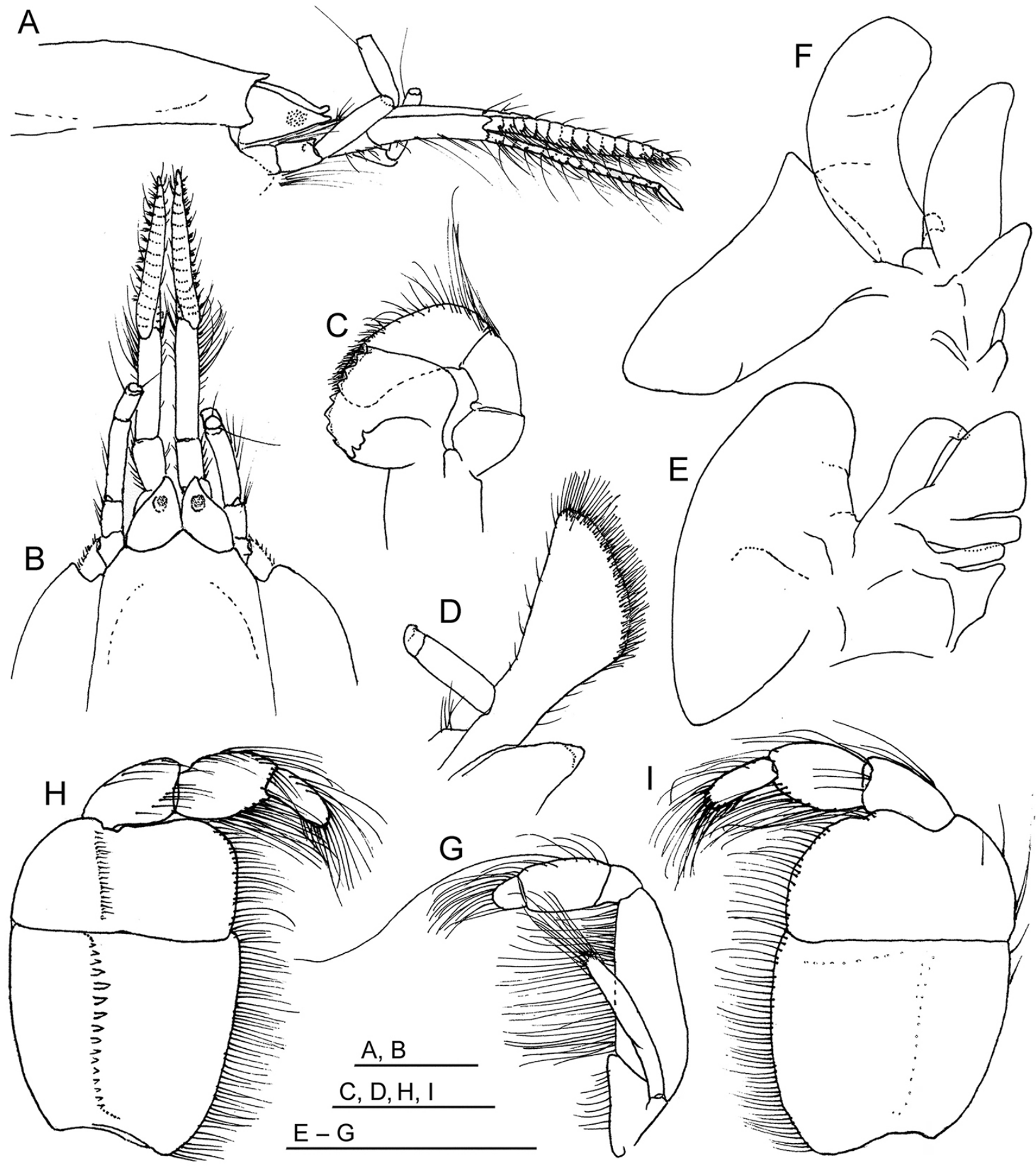

Figure 4. Gilvossius fredericqae n. sp., female holotype, pocl $4.0 \mathrm{~mm}$, northwestern Gulf of Mexico, off Texas, $98 \mathrm{~m}$ depth (USNM 1607374 = ULLZ 17894): A, B, anterior carapace, eyes, and peduncles, lateral and dorsal; C, right mandible, internal; D, right first maxilla, external; E, right second maxilla without setae, external; F, right first maxilliped without setae, external; G, right second maxilliped, external; H, I, right third maxilliped, internal and external. Scale bars $=1.0 \mathrm{~mm}(\mathrm{~A}, \mathbf{B}, \mathbf{E}-\mathbf{G}), 0.5 \mathrm{~mm}(\mathrm{C}, \mathrm{D})$.

male, pocl $2.1 \mathrm{~mm}$ (USNM $1607381=$ ULLZ 17497), BLM/STOCS station 3/I-2, depth 134 m, 27 $34^{\prime} \mathrm{N}$ 9607’W, 1 June 1977.
Morphological diagnosis. Antennular peduncle third article 3-3.5 times length of second article (both juveniles and mature adults). Adult eyestalks 


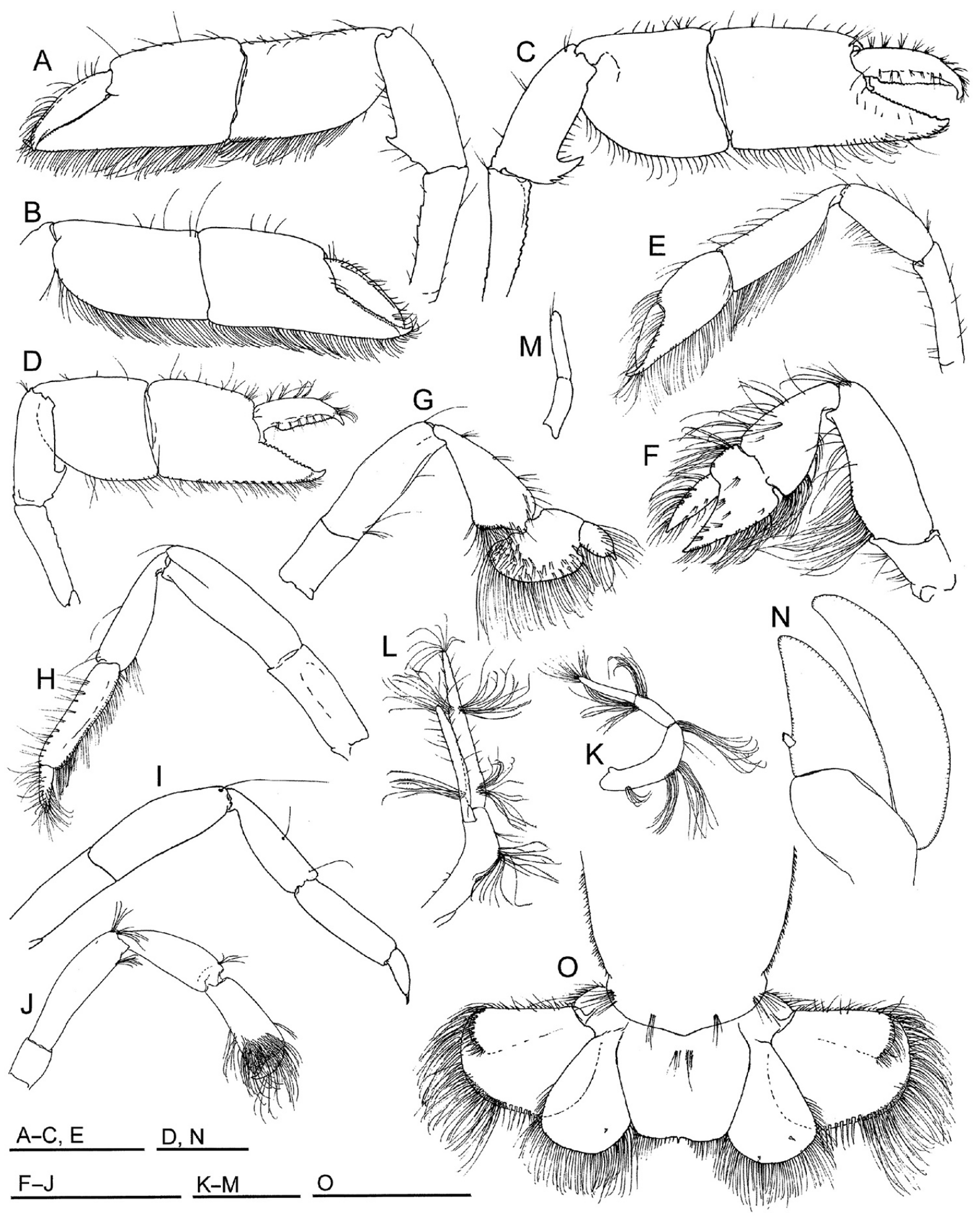

Figure 5. Gilvossius fredericqae n. sp. A, B, E-G, K, L, N, O, female holotype, pocl $4.0 \mathrm{~mm}$, northwestern Gulf of Mexico, off Texas, 98 m depth (USNM 1607374 = ULLZ 17894); C, H-J, ovigerous female paratype, pocl $3.6 \mathrm{~mm}$, northwestern Gulf of Mexico, off Texas, 131 m depth (USNM 1607376 = ULLZ 17903); D, juvenile male paratype, pocl $2.2 \mathrm{~mm}$, northwestern Gulf of Mexico, off Texas, 125 m depth (USNM 1607379 = ULLZ 17906); M, male paratype, pocl $2.7 \mathrm{~mm}$, northwestern Gulf of Mexico, off Texas, $106 \mathrm{~m}$ depth (USNM 1607375 = ULLZ 17495). A, major cheliped of female, right, internal; B, same, external; C, major cheliped of ovigerous female, left internal; D, major cheliped of juvenile male, internal; E, minor cheliped of female, left, external; F, second pereopod, left, external; G, third pereopod, right, external; H, fourth pereopod, right, internal; I, same, without setae, external; J, fifth pereopod, right, external; K, first pleopod, female, right, external; L, second pleopod, female, right, external; M, first pleopod, male, right, external; N, third pleopod, right, anterior; $\mathbf{O}$, telson and uropods. Scale bars $=2.0 \mathrm{~mm}(\mathbf{A}-\mathbf{C}, \mathbf{E}, \mathbf{F}-\mathbf{J}, \mathbf{O}), 1.0 \mathrm{~mm}(\mathrm{D}, \mathbf{K}, \mathbf{M}, \mathbf{N})$. 


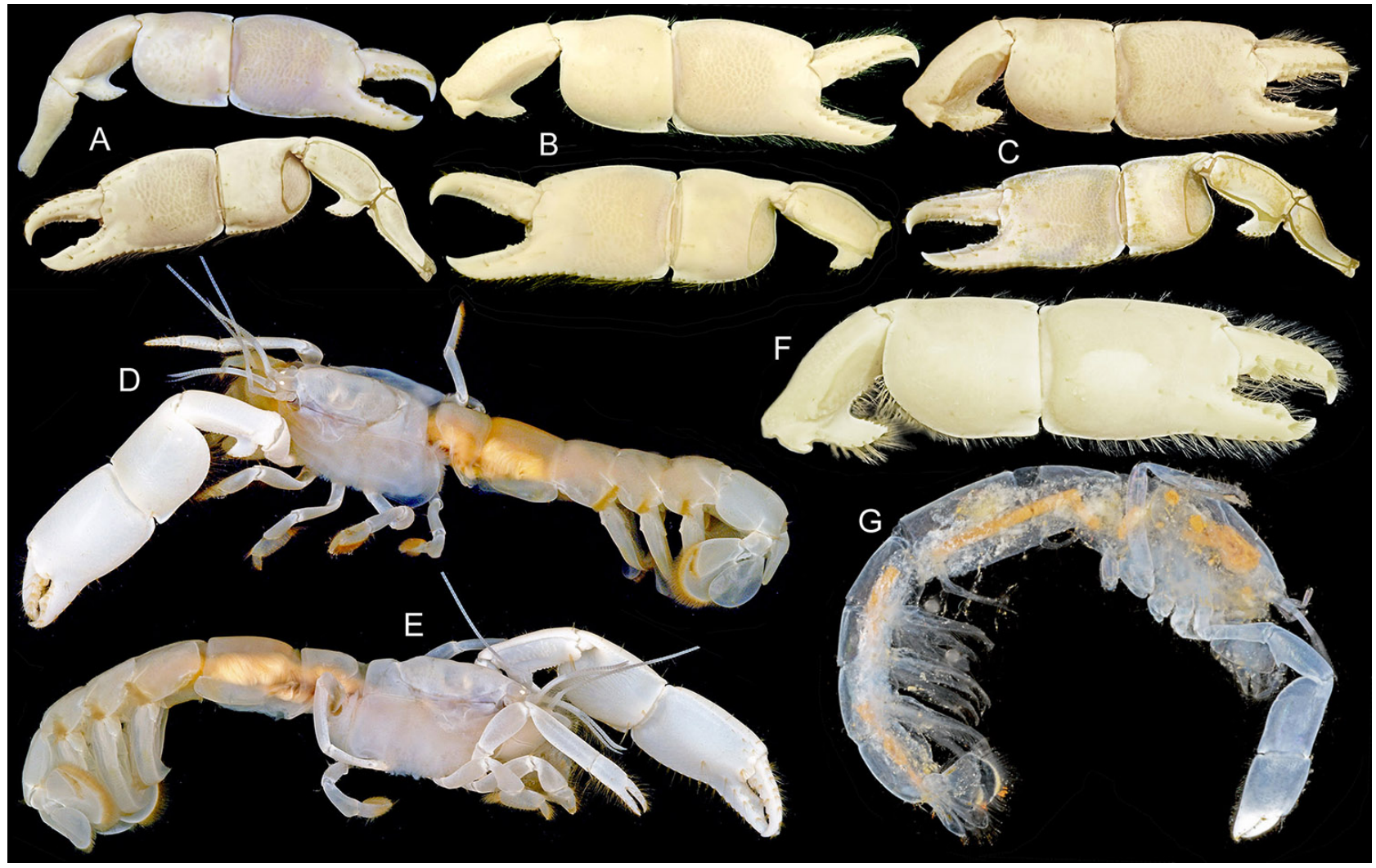

Figure 6. Gilvossius setimanus s.s. (A-C), Gilvossius howellorum n. sp. (D-F), Gilvossius fredericqae n. sp. (G). A, male, preserved major cheliped, external above, internal below, prpdl 16.1 mm (USNM 9238), Massachusetts; B, female, preserved major cheliped, external above, internal below, prpdl $16.1 \mathrm{~mm}$ (USNM 9238), Massachusetts; C, male, preserved major cheliped, external above, internal below, prpdl $18.6 \mathrm{~mm}$, pocl $15.5 \mathrm{~mm}$ (USNM 20869), Rhode Island; D, E, male holotype, pre-preservation specimen in lateral views, pocl 12.4 mm (USNM 1546234 = ULLZ 12183) Tampa Bay, western Florida; F, male paratype, preserved major cheliped, external, prpdl $15.0 \mathrm{~mm}$ (USNM uncataloged) Anna Maria Island Causeway, western Florida; G, female holotype, preserved specimen in lateral view, pocl $4.0 \mathrm{~mm}$ (USNM 1607374 = ULLZ 17894) northwestern Gulf of Mexico shelf, off Texas.

terminated in short, subtriangular, weakly divergent tips. Second maxilliped exopod length less than that of endopod merus, endopod propodus robust, length no more than twice propodus width. Third maxilliped with operculiform ischium-merus subovoid, width of ischium about equal to or greater than length. Male major chela fixed finger opposable margin usually lacking enlarged primary tooth or with any enlarged tooth positioned at or proximal to midlength, opposable margin little if any more coarsely granulate proximally than distally. Third pereopod propodus inferodistal margin not strongly cuspate, regularly arcuate, marginal setation not strongly clustered on elevations along edge. Telson subquadrate, posterior margin truncate, weakly bilobate, small median spine (sometimes minute vestige) on margin centered in shallow depression.

Description. Carapace frontal margin with short, broad, triangular rostrum, rostrum flattened in lateral view, terminally subacute, not reaching to corneas of eyestalks, rostral base flanked laterally by low, bluntly subtriangular shoulders forming orbits (Fig. 4A, B); rostral tip not exceeding $1 / 2$ length of eyestalks in dorsal view; dorsal oval weakly defined (Fig. 6G), obscure near post-rostral midline.

Eyestalks elongate, subtriangular, reaching to penultimate (second) article of antennular peduncle, carried slightly deflected, slightly divergent tips subacute, slightly upturned distally (Fig. 4A, B); medial borders of stalks diverging in distal half, dorsal surfaces elevated near medial borders, sloping to more narrowly flattened distolateral margins; corneal surface weakly faceted.

Antennular peduncle longer and distinctly heavier than antennal peduncle, length of distal antennular peduncle article less than 2 times length of distal antennal peduncle article (Fig. 4A, B); second (penultimate) article shorter than basal, third (distal) 
article about 2.5 times length of second; second and third (more so) articles with scant distoventrally directed tufts of long setae in broken ventromesial and ventrolateral rows. Antennular flagellum dorsal and ventral rami longer than third (distal) article of peduncle, ventral with some longer setae than dorsal ramus; dorsal ramus heavier than ventral over full length, subterminal articles fringed with, dense ventral aesthetascs. Antennal peduncle reaching to distal 1/4 of third antennular peduncle article; basal article dorsolateral carina arched to form lip above excretory pore; length of second article exceeding width, distal articulation to third article with small triangular scaphocerite; fourth article slightly exceeding combined lengths of first three, distinctly longer than fifth, fourth and fifth with sparse ventral setae; fifth article little if any heavier than fourth. Antennal flagellum unknown.

Mandibular palp 3-segmented, elongate third article heavy, more so than second, arched, dense elongate setae distally on second article and proximally on third, dense short stiff brush of setae on distal half of third (Fig. 4C); gnathal lobe of mandible subquadrate, distolateral shoulder forming broadly rounded obtuse angle, incisor process with about 9 well-defined subtriangular corneous teeth on cutting margin, concave internal face with thickened lip giving rise to weakly molar process bearing several small corneous teeth positioned proximal and internal to incisor teeth. First maxilla endopodal palp narrow, tip of terminal article deflected (Fig. 4D); proximal endite forming obtusely angular mesial lobe; distal endite elongate, broadening distally to densely setose terminal fan. Second maxilla margins setose, endopod narrow, strap-like, terminus wrapping behind adjacent endite (Fig. 4E); first and second endites each longitudinally subdivided, exopod forming large broadly cupped scaphognathite, distal lobe rounded, proximal subangular.

First maxilliped margins setose, endopod very small, concealed between base of distal endite and exopod (Fig. 4F); distal endite weakly arcuate, narrowing distally to rounded terminus, external surfaces densely setose medially and terminally; exopod elongate, broadly strap-like, distinctly arcuate, incompletely divided by suture, close-set patch of setae on mesial margin near oblique suture; epipod as long as exopod, broadly subrectangular, posterior lobe weakly if at all narrowed, anterior lobe narrowing to rounded acute angle.

Second maxilliped small; endopod mesial margin densely lined by long setae, merus mesial margin nearly straight, lateral margin arched, article narrowing distally, length no more than 3 times width, exceeding combined lengths of carpus, propodus, and dactylus; length of short, robust propodus less than 2 times width, length less than $1 / 2$ length of merus (Fig. 4G); dactylus about as long as broad, rounded terminally; exopod narrow, strap-like, carried closely against internal surface of endopod, shorter than endopodal merus, terminally rounded, bearing long distal setae; vestigial branchiae lacking.

Third maxilliped lacking exopod, ischiummerus broadly operculate in form, palp digitiform (Fig. 4H, I); endopod fringed by long setae, especially mesial margins of ischium and merus, along with most of palp articles; ischium subquadrate, greatest length less than or near equal to greatest width, internal surface with longitudinal, weakly sinuous row of terminally cornified spiniform teeth forming distinct crista dentata; merus much broader than long, length greater than $1 / 2$ length of ischium; carpus as broad as propodus, both longer than broad, both with a few tufts of elongate setae on internal surface, propodus robust, subfusiform, length much less than 2 times width; dactylus digitiform, length exceeding 2 times breadth, very weakly arcuate, terminally bearing long, stiff bristles.

First pereopods strongly heterochelous in both sexes (Figs. 5A-E, 6G); major cheliped located on either right or left side, typically heavier, stouter in mature male than in female; ischium slender, superior margin slightly bowed inward or sinuous, inferior marginal carina weakly armed by row of low denticles, strongest distally; merus superior margin mostly smooth, sometimes roughened by few low tubercles in proximal $1 / 4$, sloping smoothly slightly depressed longitudinal sulcus above ventral keel; inferior (flexor) margin forming keel bearing sharply spiniform lobe in posterior $1 / 3$, lobe slightly excavate on external side, broad terminal spine of lobe distally directed, variably hooked, proximal margin of lobe usually armed with 1-3 additional denticles or spines; carpus broad, subquadrate to subrectangular, superior and inferior 
margins keeled, superior margin bearing few short setae, inferior margin more densely setose, terminating distally in rounded angular corner; propodus broad, heavy, median length of postdactylar palm slightly less than to slightly exceeding length of carpus, less than two times length of fixed finger, superior and inferior margins keeled proximally, inferior margin with rows of punctae to internal and external sides bearing tufts of long setae, sparsely setose along superior margin, fixed finger opposable margin usually lacking enlarged primary tooth or with any enlarged tooth positioned at or proximal to midlength, opposable margin little if any more coarsely granulate proximally than distally, tip variably hooked; dactylus superior margin with array of punctae bearing tufts of long setae to either side of dorsal crest, extending to near tip, opposable margin lined by minute denticles, opposable margin indented or gaping to varied degree in proximal 1/4, tip variably hooked.

Minor cheliped ischium narrowly elongate (Fig. 5E), inferior margin unarmed or with few very low denticles; merus subrectangular, unarmed; carpus narrow at proximal articulation, elongate with parallel superior and inferior margins in distal half, less than twice length of palm; inferior margins of carpus and propodus bearing longer, denser setae than superior; fixed finger length approximating length of palm, opposable margin at most minutely serrate, otherwise unarmed; dactylus weakly sinuous, fingers closely opposed, minimal gape if any, tips acute.

Second pereopod chelate, fingers short, not exceeding height of palm; flexor margin of merus and carpus lined by long regularly spaced setae, inferior margin of propodus lined by long regularly spaced setae becoming stiffer and more hooked distally, similar to tufts along extensor margin of dactylus (Fig. 5F); external surfaces of distal propodus and dactylus bearing few flattened tufts of setae.

Third pereopod merus length less than 3 times width; propodus inferodistal margin not distinctly strongly cuspate, lobe regularly arcuate with marginal setation not strongly clustered on elevations (Fig. 5G), external surface partially covered by tufts of short setae; dactylus tear-shaped, concealed by long dense setae on external surface, article terminating in elongate, narrow, laterally directed corneous spine. Diameter of female gonopore $1 / 2$ length of coxa.
Fourth pereopod not obviously subchelate, inferodistal corner of propodus concealed by dense setation, not produced (Fig. 5H, I); dactylus elongate, tapering distally to narrow corneous tip forming distolaterally directed talon concealed by dense setation.

Fifth pereopod minutely chelate to subchelate terminally amid dense setation, fixed finger short, subtriangular, no longer than breadth at base (Fig. 5J); propodus with distal fields of, close-set setae on internal and external surfaces.

Branchiae limited to pair of arthrobranchs on third maxilliped and each of first through fourth pereopods.

Pleonal tergites mostly smooth dorsally (Fig. 6G). First pleonal tergite lightly sclerotized dorsally, broad transverse depression or furrow in anterior half, extended posteroventrally, sclerite extended posteroventrally as undivided lobe. Second tergite about $1 \frac{1 / 2}{2}$ times length of first, tergite ventral margin weakly bowed, lined by long setae, rounded posterolateral lobe with long setae in patch on lower half. Third to fifth tergites each with linear patch oflong supramarginal setae on lower part of posterolateral lobe, broader patch of long setae centered higher above margin in posterior half of third tergite, at midlength of fourth tergite, in anterior half of fifth tergite. Sixth tergite with distinct posterolateral groove and short suture defining posterolateral lobe, suture not extending across tergite, lobe with submarginal tuft of stiff setae posterolaterally, posterior margin of tergite with similar tuft to mesial side of lobe (Fig. 5O). Ventral surfaces of pleonal somites mostly membraneous, lacking extensive armor of sclerotized plates or dense tubercles embedded in integument.

Female with first and second pleopods; first uniramous, composed of 3 articles, bearing tufts of elongate setae; second biramous (Fig. 5K, L), exopod with scattered tufts of elongate setae, narrow, bowed, shorter than endopod when flexed against it, endopod with tufts of elongate setae, including at tip of appendix interna. Male with small uniramous first pleopod composed of 2 articles, lacking second male pleopod (Fig. 5M). Third to fifth pleopods forming large, posteriorly cupped fans, endopod of each subtriangular with short heavy appendix interna embedded in but extending short distance beyond mesial margin, opposed surfaces on appendixinternae 
of two sides each with small field of microscopic hook setae (Fig. $5 \mathrm{~N}$ ).

Telson wider than long, subquadrate, posterior margin truncate, weakly bilobate, bearing small median marginal spine (sometimes minute vestige) centered in shallow depression (Fig. 5O); dorsal surface with weak median elevation in anterior $1 / 4$ bearing bilaterally separated fields or tufts of setae.

Uropodal endopod broadly ovate, about $1 \frac{1 / 2}{2}$ times longer than broad, posterior margin with continuous fringe of long setae, lacking posterolateral development of stiff spines and bristles, dorsal surface at most with few short spiniform setae (Fig. 5O); exopod anterodorsal plate small, distinct distally, weakly evident proximally, not reaching to endopod margin, setae along posterodistal edge of plate including spiniform bristles posteriorly, grading laterally to thinner, dense, elongate setae of exopod distal margin, continuous dense fringe oflong setae on exopod distal margin replaced posteriorly by marginal row of heavy stiff spines or bristles, posterior margin of exopod very weakly sinuous.

Color. Unknown in life, as all present specimens are preserved and are largely translucent except for opaque whitish at thickened areas of integument, especially at tips of cheliped fingers.

Size. Largest male pocl $2.7 \mathrm{~mm}$, largest female pocl $4.0 \mathrm{~mm}$. Smallest ovigerous female pocl $3.6 \mathrm{~mm}$. Range of embryo diameters, measured as greatest dimension, $0.65-0.75 \mathrm{~mm}$.

Habitat. The depth range of 98-104 $\mathrm{m}$ for this species far exceeds depths reported for confirmed specimens of $G$. setimanus, the species with which it was long confused under the junior synonym $C$. atlantica. This range represents the deepest stations for box core collections of burrowing infauna along transects of the 1976-1977 BLM/STOCS survey off the Texas coast, the only sites in that extensive survey where G. fredericqae n. sp. was found to occur. In addition to collection depths, salinity and sedimentary profiles were reported for this species by Rabalais et al. (1981: fig. 6). These show its restriction to high salinity offshore waters in muddy substrates that include little sand, in contrast to the nearshore settings and sandier substrates occupied by its presently known western Atlantic congeners.

Distribution. Known only from offshore continental shelf waters of Texas in the northwestern Gulf of Mexico.

Etymology. This species is named for Suzanne Fredericq, a distinguished seaweed specialist based at the University of Louisiana - Lafayette, cherished friend, and respected colleague with whom we have very productively and enjoyably collaborated during multiple research cruises over several decades. Her broad general knowledge of marine biota and contagious enthusiasm have inspired us no less than the many students and postdoctoral associates that she has trained.

Remarks. Several morphological features of this species lead us to make its assignment to Gilvossius provisional, pending our securing of gene-sequence quality specimens for analyses to confirm its generic affiliations. In particular, the posteriorly truncate telson differs from those of most other species of Gilvossius, as redefined by Poore et al. (2019). Also, at least one of the immature males has a small first pleopod (Fig. 5M), though no second pleopod is evident so far as known from limited available material.

No example exists of a fully mature male cheliped among presently available specimens of this species, many of which are fragmentary or immature. Intending to more fully represent characters of $C$. atlantica in the course of reporting the species from the Gulf of Mexico, Rabalais et al. (1981: fig. 2B, C, E, F, H) illustrated the third maxilliped, cheliped, carapace front with eyes and peduncles, minor cheliped, and tail fan from a female museum specimen that had been collected off North Carolina (USNM 51007), having concluded at the time that both populations represented a single species. These selected figures, including the cheliped with a distinct tooth on its opposable margin, are now identifiable as G. setimanus s.s. However, with Chorazole Black E staining, one of the unsexed immature specimens that those authors listed from the Gulf of Mexico can now be definitively identified as a male, and its cheliped is intact (Fig. 5D). While the propodus and carpus of 
this male cheliped are proportionally broader than in the illustrated mature females (Fig. 5A-C), dentition on the cutting edges of the fingers is similar in both sexes, with neither having an enlarged primary tooth on the fixed finger as typically found in G. setimanus and G. howellorum n. sp. Even so, a mature male is required to confirm that this persists in the adult of that sex, just as it appears to do in females.

We have not definitively assigned a small (pocl $3.5 \mathrm{~mm}$ ) mature female cataloged as G. setimanus (USNM 256541), taken by the Johnson Sea Link submersible at $274 \mathrm{~m}$ depth in the Bahamas. While from much deeper water than the northwestern Gulf of Mexico materials, this specimen resembles $G$. fredericqae n. sp. in being sexually mature at the same size and in having a median spine on a somewhat truncate posterior margin. It also shares a third pereopod propodus that does not have setation distinctly clustered along a cuspate ventral margin and closely resembles $G$. fredericqae n. sp. in general characteristics of the anterior carapace, eyestalks, peduncles, and most features of the major cheliped. However, the dactylus of the major chela differs in having a deep narrow incision proximally, the minor chela fingers gape more conspicuously, and the minor cheliped propodus and carpus are relatively broader than in available specimens of $G$. fredericqae n. sp. While this specimen clearly does not represent G. setimanus s.s., we also are reluctant to assign it to $G$. fredericqae n. sp. and defer more definitive treatment in hopes that additional materials from this depth and location become available.

\section{ACKNOWLEDGMENTS}

The late Raymond Manning, in the course of previous collaborations with DLF, first called attention to issues treated in this paper. Among many other individuals who in varied ways assisted in field or laboratory phases of this project we thank Kathryn Ahlfeld, Karen Barkel, Amanda Bemis, Christopher Boyko, Daniel Drew, Peter Dworschak, Jennifer Felder, Richard Kalke, Paul Klerks, Woody Lee, Rafael Lemaitre, Emma Palacios-Theil, Valerie Paul, Gustav Paulay, Simon Pecnik, Gary Poore, Nancy Rabalais, Karen Reed, Lourdes Rojas, and Justin Scioli. The project was supported under funding to DLF from
U.S. National Science Foundation grants NSF/ BS\&I DEB-0315995 and NSF/AToL EF-0531603, U.S. Department of Energy grant no. DE-FG0297ER1220, NSF RAPID grant no. DEB-1045690, and the Gulf of Mexico Research Initiative (GoMRI). RR acknowledges PRODEP-SEP, Mexico, through the program "Apoyo a la Incorporación de NPTC (Ago/1/2018 -Jul/31/2019)”. This is contribution number 207 of the UL-Lafayette Laboratory for Crustacean Research and number 1129 for the Smithsonian Marine Station, Ft. Pierce, Florida.

\section{References}

Abele, L.G. and Kim, W. 1986. An illustrated guide of the marine decapod crustaceans of Florida. State of Florida Department of Environmental Regulation, Technical Series, 8, Parts 1, 2:1-760.

Biffar, T.A. 1970. Three new species of callianassid shrimp (Decapoda, Thalassinidea) from the western Atlantic. Proceedings of the Biological Society of Washington, 83: 35-50.

Biffar, T.A. 1971a. The genus Callianassa (Crustacea, Decapoda, Thalassinidea) in South Florida, with keys to the western Atlantic species. Bulletin of Marine Science, 21: 637-715.

Biffar, T.A. 1971b. New species of Callianassa (Decapoda, Thalassinidea) from the western Atlantic. Crustaceana, 21: 225-236.

Borradaile, L.A. 1903. On the classification of the Thalassinidea. Annals and Magazine of Natural History, (series 7), 7(12): 534-551, 638.

De Kay, J.E. 1844. Crustacea. In: Zoology of New-York; or the New-York fauna; comprising detailed descriptions of all the animals hitherto observed within the state of New-York, with brief notices of those occasionally found near its borders, and accompanied by appropriate illustrations. Part VI, p. 1-70, pl. 1-13. Albany, Carroll and Cook.

de Man, J.E. 1928a. A contribution to the knowledge of twentytwo species and three varieties of the genus Callianassa (Leach). Capita Zoologica, 2(6): 1-56, pls. 1-12.

de Man, J.E. 1928b. The Decapoda of the Siboga-Expedition. Part 7. The Thalassinidae and Callianassidae collected by the Siboga-Expedition with some remarks on the Laomediidae. Siboga Expeditie, 39 (A6): 1-187, pls. 1-20.

Dana, J.D. 1852. Macroura. Conspectus Crustaceorum \& Conspectus of the Crustacea of the Exploring Expedition under Capt. C. Wilkes, U.S.N. Proceedings of the Academy of Natural Sciences of Philadelphia, 6: 6-28.

Dworschak, P.C.; Felder, D.L. and Tudge, C.C. 2012. Infraorders Axiidea de Saint Laurent, 1979 and Gebiidea de Saint Laurent, 1979 (formerly known collectively as Thalassinidea). p. 109219. In: F.R. Schram and J.C. von Vaupel Klein (eds), Treatise on Zoology - Anatomy, Taxonomy, Biology. The Crustacea (complementary to the volumes of the Traité de Zoologie), Vol. 9, Part B. Leiden, Netherlands, Koninglijke Brill. 
Felder, D.L.; Álvarez, F.; Goy, J.W. and Lemaitre, R. 2009. Decapoda (Crustacea) of the Gulf of Mexico, with comments on the Amphionidacea. p. 1019-1104. In: D.L. Felder and D.K. Camp (eds), Gulf of Mexico Origin, Waters, and Biota. Volume 1, Biodiversity. College Station, Texas A\&M University Press.

Felder, D.L. and Robles, R. 2009. Molecular phylogeny of the family Callianassidae based on preliminary analyses of two mitochondrial genes. p. 327-342. In: J.W. Martin; K.A. Crandall and D.L. Felder (eds), Crustacean Issues: Decapod Crustacean Phylogenetics. Boca Raton, Florida, Taylor and Francis/CRC Press.

Fish, C.J. 1925. Seasonal distribution of the plankton of the Woods Hole region. Bulletin of the United States Bureau of Fisheries, 41: 91-178, 81 graphs.

Fowler, H.W. 1912. The Crustacea of New Jersey. Annual Report of the New Jersey State Museum, 1911: 29-650, pls. 1-150.

Frankenberg, D. and Leiper, A.S. 1977. Seasonal cycles in benthic communities of the Georgia continental shelf. p. 383-397. In: B.C. Coull (ed), Ecology of Marine Benthos, Columbia, University of South Carolina Press.

Gurney, R. 1944. The systematics of the crustacean genus Callianassa. Proceedings of the Zoological Society of London. Series B, Systematic and Morphological, 114: 82-90.

Hay, W.R. and Shore, C.A. 1918. The decapod crustaceans of Beaufort, N.C, and the surrounding region. Bulletin of the United States Bureau of Fisheries, 35 (for 1915 and 1916): 369-475, pls. 25-39.

Heard, R.W.; King, R.A.; Knott, D.M.; Thoma, B.P. and ThorntonDeVictor, S. 2007. A guide to the Thalassinidea (Crustacea: Malacostraca: Decapoda) of the South Atlantic Bight. NOAA Professional Paper NMFS, 8: 1-30.

Holmes, S.J. 1904. On some new or imperfectly known species of west American Crustacea. Proceedings of the California Academy of Sciences, 3: 307-322, pls. 35-37.

Kingsley, J.S. 1878. Appendix. List of Decapod Crustacea of the Atlantic Coast, Whose Range Embraces Fort Macon. Proceedings of the Academy of Natural Sciences of Philadelphia, 30: 316-330.

Kingsley, J.S. 1879. On a collection of Crustacea from Virginia, North Carolina, and Florida with a revision of the genera of Crangonidae and Palaemonidae. Proceedings of the Academy of Natural Sciences, Philadelphia, 31: 383-427.

Kingsley, J.S. 1899. Synopses of North-American invertebrates. IV. Astacoid and thalassinoid Crustacea. American Naturalist, 33: 819-824.

Manning, R.B. 1987. Notes on western Atlantic Callianassidae (Crustacea: Decapoda: Thalassinidea). Proceedings of the Biological Society of Washington, 100: 386-401.

Manning, R.B. and Felder, D.L. 1991. Revision of the American Callianassidae (Crustacea, Decapoda, Thalassinidea). Proceedings of the Biological Society of Washington, 104: 764792.

Manning, R.B. and Felder, D.L. 1992. Gilvossius, a new genus of callianassid shrimp from the eastern United States (Crustacea:
Decapoda: Thalassinidea). Bulletin of Marine Science, 49 (for 1991): 558-561.

Poore, G.C.B.; Dworschak, P.C.; Robles, R.; Mantelatto, F. and Felder, D.L. 2019. A new classification of Callianassidae and related families (Crustacea: Decapoda: Axiidea) derived from a molecular phylogeny with morphological support. Memoirs of Museum Victoria, 78: 73-146.

Rabalais, N.N.; Holt, S.A. and Flint, R.W. 1981. Mud shrimps (Crustacea, Decapoda, Thalassinidea) of the northwestern Gulf of Mexico. Bulletin of Marine Science, 31: 96-115.

Rathbun, M.J. 1905. Fauna of New England. 5. List of the Crustacea. Occasional Papers of the Boston Society of Natural History, 7: 1-117.

Rathbun, M.J. 1926. The fossil stalk-eyed Crustacea of the Pacific slope of North America. United States National Museum Bulletin, 138: vii+155p., 39 pls.

Rathbun, M.J. 1935. Fossil Crustacea of the Atlantic and Gulf Coastal Plain. Geological Society of America, Special Paper, 2: vii+160p, 26 pls.

Robles, R. and Felder, D.L. 2015. Molecular phylogeny of the genus Lepidophthalmus (Decapoda, Callianassidae), with re-examination of its species composition. Zootaxa, 4020: 453-472.

Robles, R.; Tudge, C.C.; Dworschak, P.C.; Poore, G.C.B. and Felder, D.L. 2009. Molecular phylogeny of the Thalassinidea based on nuclear and mitochondrial genes. p. 309-326. In: J.W. Martin; K.A. Crandall and D.L. Felder (eds), Crustacean Issues: Decapod Crustacean Phylogenetics. Boca Raton, Florida, Taylor and Francis/CRC Press.

Robles, R.; Dworschak, P.C.; Felder, D.L.; Poore, G.C.B. and Mantelatto, F.L. 2020. A molecular phylogeny of Callianassidae and related families (Crustacea: Decapoda: Axiidea) with morphological support. Invertebrate Systematics, 34: 113-132.

Saint Laurent, M. de. 1979. Vers une nouvelle classification des Crustacés Décapodes Reptantia. Bulletin de l'Office National des Pêches République Tunisienne, Ministere de L'Agriculture 3: 15-31.

Sakai, K. 1999. Synopsis of the family Callianassidae, with keys to subfamilies, genera and species, and the description of new taxa (Crustacea: Decapoda: Thalassinidea). Zoologische Verhandelingen, 326: 1-152.

Sakai, K. 2005. Callianassoidea of the World (Decapoda: Thalassinidea). Crustaceana Monographs, 4. Leiden, Brill, 286p.

Sakai, K. 2011. Axioidea of the World and a Reconsideration of the Callianassoidea (Decapoda, Thalassinidea, Callianassida). Crustaceana Monographs, 13. Leiden, Brill, 520p.

Schmitt, W.L. 1935. Mud shrimps of the Atlantic coast of North America. Smithsonian Miscellaneous Contributions, 93: 1-21.

Sumner, F.B.; Osburn, R.C. and Cole, C. 1913. A biological survey of the waters of Woods Hole and vicinity. Section I. Physical and zoological. Bulletin of the Bureau of Fisheries, 31: 1-200.

Tudge, C.C.; Poore, G.C.B. and Lemaitre, R. 2000. Preliminary phylogenetic analysis of generic relationships within the Callianassidae and Ctenochelidae (Decapoda: Thalassinidea: Callianassoidea). Journal of Crustacean Biology, 20 (Special Issue 2): 129-149. 
Verrill, A.E.; Smith, S.I. and Harger, O. 1873. D.-Catalogue of the marine invertebrate animals of the southern coast of New England, and adjacent waters. p. 537-747. In: A.E. Verrill and S.I. Smith (eds), Report upon the invertebrate animals of Vineyard Sound and the adjacent waters, with an account of the physical characters of the region. p. 295-778, 38 plates. Extracted from: S.F. Baird, Report on the condition of the sea fisheries of the south coast of New England in 1871 and 1872. United States Commission of Fish and Fisheries, 1, XLVII-I, 852p.
Williams, A.B. 1965. Marine decapod crustaceans of the Carolinas. Fishery Bulletin, 65: xi+298p.

Williams, A.B. 1974. Marine fauna and flora of the northeastern United States. Crustacea: Decapoda. NOAA Technical Report, NMFS Circular, 389: 1-50.

Williams, A.B. 1984. Shrimps, lobsters, and crabs of the Atlantic coast of the eastern United States, Maine to Florida. Washington, D.C., Smithsonian Institution Press, 550p. 